BIOMA 10 (1), 2015

Biologi UNJ Press

ISSN : 0126-3552

\title{
PENGAMATAN AKTIVITAS TIKUS WISTAR JANTAN DENGAN ALAT OPTO- VARIMEX® PADA KONDISI DIET TINGGI MINYAK TRANS
}

Male Wistar Rat Activity Monitoring with Opto-Varimex ${ }^{\circledR}$ in Conditions Due to High Trans Fat Diet.

\section{NURUL MASYITA ${ }^{1}$, KOEKOEH SANTOSO ${ }^{1}$,NASTITI KUSUMORINI ${ }^{1}$, ARYANI SISMIN SATYANINGTIJAS ${ }^{1}$ \&ATIN SUPIYANI ${ }^{2}$}

${ }^{1}$ Fakultas Kedokteran Hewan, Institut Pertanian Bogor, Jl. Raya Darmaga Kampus IPB Darmaga Bogor 16680

Jawa Barat, Indonesia

${ }^{2}$ Jurusan Biologi FMIPA Universitas Negeri Jakarta (UNJ). Jl. Pemuda No. 10 Rawamangun, Jakarta Timur. 13220.

Indonesia

Email: atinsupiyani78@gmail.com

Tanggal publikasi online:

\section{ABSTRACT}

Excessive energi consumption of high-fat diet increase the body's adipose tissue which also affect the increased secretion of leptin, this is because leptin secretion is proportional to the mass of adipose tissue. Leptin activates the lateral hypothalamus as the center of hunger and feeding activity. The aim of this study was to obtain the relationship between high trans fat feeding on male Wistar rats and feeding activity. This method uses male Wistar rats (Rattus norvegicus) as an animal model. Sixteen rats were grouped into 4 treatment groups. The first group was given additional feed $20 \%$ trans fat, the second group was given additional feed $40 \%$ trans fat, a third group was given additional feed $60 \%$ trans fat, and the last as a control group. This feed was given once a day for 70 days. Observation of activities perform using Opto-varimex ${ }^{\circledR}$ auto-track system ver. 4.31. The results showed an corellation between activity based doses of trans fat.

Keywords: Opto-varimex®, Trans fat, Activity, Wistar rat.

\section{PENDAHULUAN}

Gaya hidup masyarakat Indonesia dengan pola makan yang tinggi kalori merupakan faktor awal pemicu berbagai penyakit. Lemak merupakan salah satu sumber kalori dalam makanan. Secara nasional, rata-rata konsumsi lemak penduduk di Indonesia adalah $47.2 \mathrm{~g}$ atau $25.6 \%$ dari total konsumsi energi. Hal ini berarti konsumsi energi dari lemak pada penduduk Indonesia lebih dari $25 \%$ dari total konsumsi energi dan melebihi nilai yang dianjurkan oleh Pedoman Umum Gizi Seimbang (Riskesdas 2010). WHO (2003) merekomendasikan konsumsi lemak trans tidak lebih dari $1 \%$ total 
konsumsi energi, hal ini dikarenakan konsumsi lemak trans yang berlebihan memberikan efek buruk terhadap kesehatan. Penelitian yang dilakukan oleh Mozaffarian et al. (2006) mendapatkan hasil bahwa konsumsi $2 \%$ asam lemak trans dari total asupan energi meningkatan resiko kejadian penyakit jantung koroner sebesar $23 \%$. Lemak yang biasa kita konsumsi terbagi menjadi tiga jenis yaitu lemak jenuh, lemak tak jenuh dan lemak trans. Salah satu konsumsi lemak trans didapatkan dari olahan minyak. Minyak yang mengandung asam lemak tak jenuh (Poly-unsaturated Fatty Acid/ PUFA) jika digunakan untuk menggoreng secara berulang-ulang, maka lemak tak jenuh baik dari minyak penggoreng maupun dari makanan yang digoreng akan berubah menjadi asam lemak trans (Mozaffarian et al. 2006). Tikus yang diberi pakan tinggi lemak trans terbukti mengalami peningkatan massa jaringan adiposa, hal ini serupa dengan kejadian pada manusia (corbett et al. 1986). Jaringan adiposa akan menghasilkan hormon leptin. Leptin adalah hormon polipeptida yang berasal dari sel-sel lemak, sekresi hormon ini berbanding lurus dengan massa jaringan adiposa (Guyton dan Hall 2008).

Penelitian yang dilakukan oleh Mars et al. (2006) membuktikan bahwa leptin memberikan pengaruh terhadap perilaku makan. Kadar leptin yang rendah akan meningkatkan rasa lapar dan nafsu makan. Pengaturan nafsu makan seperti kita ketahui sebelumnya diatur oleh suatu pusat lapar di hipothalamus lateral dan pusat kenyang di ventromedial hipothalamus. Adanya perangsangan di hipothalamus lateral, individu akan makan dengan rakus sedangkan apabila terjadi perangsangan di inti ventromedialis hipothalamus akan menyebabkan rasa kenyang bahkan menolak untuk makan (Schwartz 2001). Keinginan makan yang tinggi akan membuat hewan menjadi lebih aktif dan agresif. Pernyataan tersebut didukung oleh penelitian Silver dan Erecinska (1994) bahwa reseptor rasa lapar pada sistem saraf pusat mampu mengatur keinginan mencari makan.

Penelitian ini bertujuan untuk mendapatkan hubungan pemberian pakan tinggi lemak trans pada tikus jantan wistar terhadap aktivitasnya. Penelitian ini diharapkan dapat bermanfaat bagi peneliti dan masyarakat tentang dampak perubahan aktivitas yang disebabkan oleh keadaan diet tinggi lemak trans.

\section{BAHAN DAN METODE}

\section{Waktu dan Lokasi Penelitian}

Penelitian dilaksanakan dari bulan Februari sampai Mei 2014. Penelitian dilaksanakan di Unit Pengelola Hewan Laboratorium (UPHL) dan Laboratorium Fisiologi, Fakultas Kedokteran Hewan, Institut Pertanian Bogor.

\section{Alat dan Bahan}

Bahan yang digunakan dalam penelitian ini adalah tikus jantan dewasa strain Wistar (Rattus norvegicus) sebagai hewan model, berusia 12 minggu dengan bobot badan 200-250 g sebanyak 16 ekor. Pakan berupa pellet dan minum ad libitum. Minyak trans yang dipanaskan pada suhu 280 0C selama 10 menit. Alat yang digunakan dalam penelitian ini adalah kandang plastik, sonde lambung, Opto-varimex ${ }^{\circledR}$ auto-track system ver. 4.31 dan satu perangkat komputer.

\section{Prosedur Penelitian}


Minyak trans diperoleh dari minyak kelapa yang telah dipanaskan pada suhu 280 0C selama 10 menit (Tuminah 2009). Pemanasan dilakukan menggunakan oven lalu disimpan ke dalam botol untuk didinginkan pada suhu ruang. Minyak trans diberikan sebagai pakan tambahan dihitung berdasarkan perbandingan dari total konsumsi energi yang diberikan.

Tikus dipelihara dalam kandang plastik berukuran 30 x $40 \mathrm{~cm}$ dengan tutup terbuat dari kawat ram dan dialasi serbuk kayu. Tikus diberi pakan pellet standar dan minum ad libitum. Lingkungan kandang dibuat agar tidak lembab dengan sirkulasi udara baik, serta penyinaran yang cukup terang $( \pm 14$ jam$)$ dan gelap selama $( \pm 10$ jam $)$.

Tikus dikelompokkan menjadi dua kelompok yaitu kontrol (K) dan minyak trans (MT) yang terdiri dari 3 perlakuan yaitu 20\%, 40\% dan 60\% dari total energi pakan yang diberikan (Buettner et al. 2007). Kelompok kontrol berjumlah 4 ekor tikus dan kelompok perlakuan berjumlah 12 ekor tikus. Kelompok perlakuan minyak trans 20\%, 40\%, 60\% masing-masing terdiri dari 4 ekor tikus sebagai ulangan.

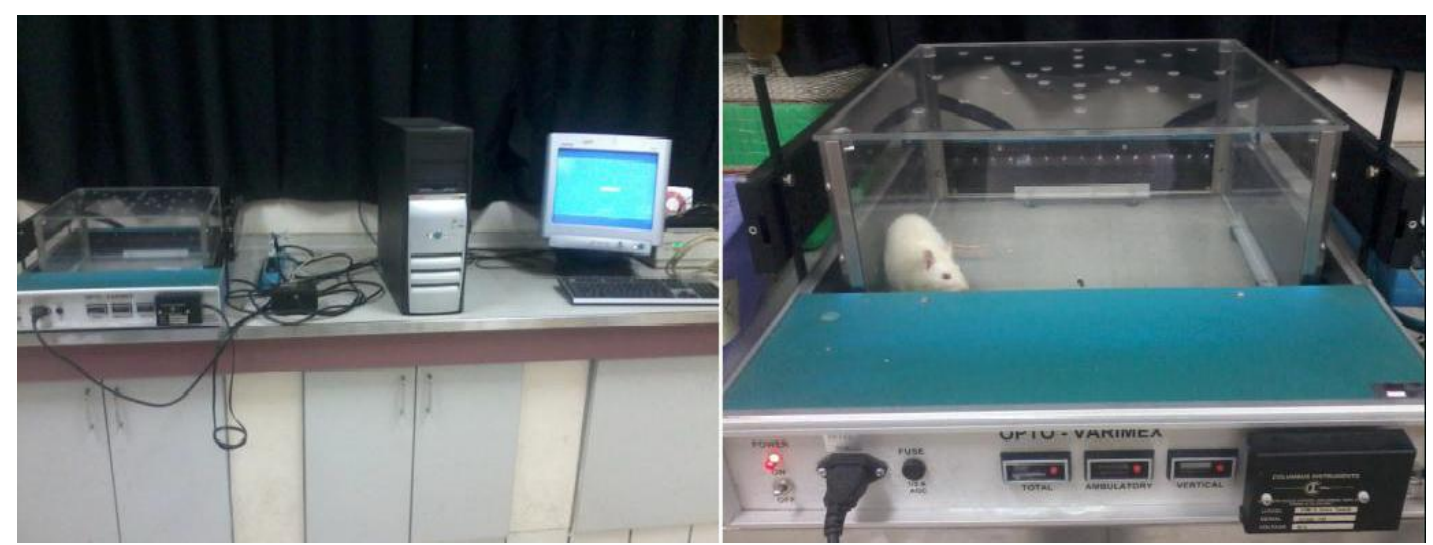

Gambar 1 Alat monitoring aktivitas Optovarimex® auto-track system ver.4.31

Pemberian minyak trans pada tikus menggunakan sonde lambung. Minyak trans yang diberikan pada tikus kelompok $20 \%$ sejumlah $1.4 \mathrm{ml}$, kelompok $40 \%$ sejumlah $2.8 \mathrm{ml}$ dan kelompok $60 \%$ sejumlah $4.2 \mathrm{ml}$, diberikan sebagai pakan tambahan dihitung berdasarkan perbandingan dari total konsumsi energi yang diberikan (Lampiran 1). Tikus dicekok minyak trans satu kali sehari pada siang hari selama 70 hari.

Semua tikus kontrol dan tikus perlakuan setelah 70 hari pencekokkan minyak trans diukur aktivitasnya. Seluruh kelompok tikus dalam kotak plastic dipindahkan menuju ruang analisa dan didiamkan selama 5 menit untuk beradaptasi dengan wilayah baru. Pengamatan aktivitas dilakukan di ruang tertutup pada siang hari dengan pencahayaan yang cukup. Sesuai dengan kelompoknya kemudian tikus ditempatkan pada wadah pengukuran aktivitas dalam Opto-varimex ${ }^{\circledR}$ auto-track system ver. 4.31. Untuk mengurangi pengaruh stres lingkungan, sebelum dimulai pengukuran hewan dimasukkan ke dalam alat selama 5 menit. Pengukuran aktivitas dilakukan sebanyak satu kali. Alat dioperasikan selama 5 menit dalam ruangan yang bebas gangguan baik suara maupun getaran guna meminimalkan pengaruh lingkungan selama proses pengukuran aktivitas.

Parameter aktivitas tikus yang diukur menggunakan Opto-varimex® autotrack system ver. 
4.31 adalah distance traveled, resting time dan ambulatory time. Distance traveled (DT) adalah jarak tempuh tikus selama 5 menit waktu pengukuran. Resting time (RT) adalah waktu yang dibutuhkan tikus untuk beristirahat atau tidak melakukan suatu gerakan. Ambulatory time (AT) adalah waktu yang dibutuhkan tikus untuk memulai suatu gerakan stereotypic tanpa perpindahan tempat.

\section{Analisis Data}

Rancangan penelitian yang digunakan adalah Rancangan Acak Kelompok (RAK) dan masingmasing perlakuan terdiri atas 4 ekor tikus sebagai ulangan. Data kuantitatif hasil pengamatan akan dianalisa menggunakan Analysis of Variance (ANOVA) dan dilanjutkan dengan uji Duncan untuk melihat perbedaan antar perlakuan dengan selang kepercayaan 95\% $(\alpha=0.05)$, serta uji regresi dengan menggunakan perangkat lunak software SAS 9.1.3 (Mattjik dan Sumertajaya 2006).

\section{HASIL DAN PEMBAHASAN}

Pemberian minyak trans dengan dosis 20\%, 40\%, 60\% dari total konsumsi energi selama 70 hari perlakuan terhadap perubahan aktivitas tikus DT, RT dan AT dapat dilihat pada Tabel 1 berikut ini.

Tabel 1 Aktivitas tikus pada pemberian minyak trans berbeda

\begin{tabular}{llll}
\hline \multirow{2}{*}{ Treatmen } & \multicolumn{3}{l}{ Aktivitas } \\
\cline { 2 - 4 } & Distance traveled $(\mathrm{cm})$ & Resting time (detik) & Ambulatory time (detik) \\
\hline Kontrol & $171.50 \pm 68.946 \mathrm{a}$ & $269.50 \pm 13.025 \mathrm{c}$ & $30.50 \pm 13.025 \mathrm{a}$ \\
MT 20\% & $274.25 \pm 94.524 \mathrm{~b}$ & $114.50 \pm 14.730 \mathrm{~b}$ & $185.5 \pm 14.730 \mathrm{~b}$ \\
MT 40\% & $520.00 \pm 130.228 \mathrm{~b}$ & $75.75 \pm 9.639 \mathrm{~b}$ & $224.25 \pm 9.636 \mathrm{c}$ \\
MT 60\% & $761.00 \pm 282.546 \mathrm{c}$ & $47.00 \pm 7.702 \mathrm{a}$ & $253.00 \pm 7.702 \mathrm{c}$ \\
\hline
\end{tabular}

Keterangan: Angka-angka pada kolom yang sama yang diikuti oleh huruf yang berbeda menunjukkan beda nyata pada taraf uji $5 \%$

Hasil pengamatan aktivitas menunjukkan bahwa semua kategori aktivitas tikus jantan kelompok perlakuan berpengaruh nyata $(\mathrm{P}<0.05)$ bila dibandingkan dengan kelompok kontrol. Adanya perbedaan data tersebut mengindikasikan bahwa pemberian minyak trans selama 70 hari memberikan pengaruh terhadap aktivitas tikus.

\section{Distance traveled (DT) atau Jarak Tempuh}

Distance traveled adalah jarak yang ditempuh oleh tikus atau perpindahan tikus dari tempat yang satu ketempat yang lain. Perpindahan tikus dapat berkaitan dengan agresivitas dalam mencari makanan dan minuman, mencari tempat perlindungan ataupun pengenalan lingkungan.

Hasil pengukuran menunjukkan, adanya peningkatan yang nyata pada perlakuan $20 \%, 40 \%$ maupun $60 \%$. Untuk mengetahui hubungan antara konsentrasi minyak trans dengan DT, dilakukan uji regresi. Hasil uji regresi (Gambar 2) menunjukkan hubungan yang erat antara peningkatan konsumsi minyak trans dengan peningkatan DT, dengan persamaan $\mathrm{y}=201.425 \mathrm{x}-71.875, \mathrm{r}=0.834$ dan R2 = 0.696. Hal ini menunjukkan bahwa penambahan minyak trans memberikan pengaruh terhadap DT sebesar 69.6\% Pemberian minyak trans pada tikus yang berlebih dapat menyebabkan 
penimbunan jaringan adiposa yang berakibat pada peningkatan bobot badan.

Penelitian yang dilakukan oleh Dhibi et al. (2011) menyatakan bahwa setelah empat minggu pemberian pakan tinggi lemak trans sebesar 20\% dari total energi pakan, menghasilkan pertambahan bobot badan sebesar $25.83 \mathrm{~g}$ lebih tinggi dibandingkan dengan tikus yang diberi pakan standar. Peningkatan massa jaringan adiposa akibat diet tinggi minyak trans akan mengakibatkan peningkatan kadar leptin dalam darah. Hal ini sesuai dengan pernyatan Guyton dan Hall (2008) bahwa meningkatnya massa adipose berbanding lurus dengan peningkatan sekresi hormon leptin. Tingginya kadar leptin dalam darah akan direspon oleh hipothalamus bagian lateral yang merupakan pusat rasa lapar (Konturek et al. 2004). Leptin bersirkulasi di otak melalui proses difusi dan menempatkan reseptor-reseptor leptin di berbagai bagian hipothalamus lateral, terutama Neuron Proopio Melanokortin (POMC) di nucleus arkuatus (Friedman dan Halaas 1998). Tikus dan manusia yang mengalami peningkatan massa jaringan adiposa menyebabkan keadaan resistensi

\section{DT}

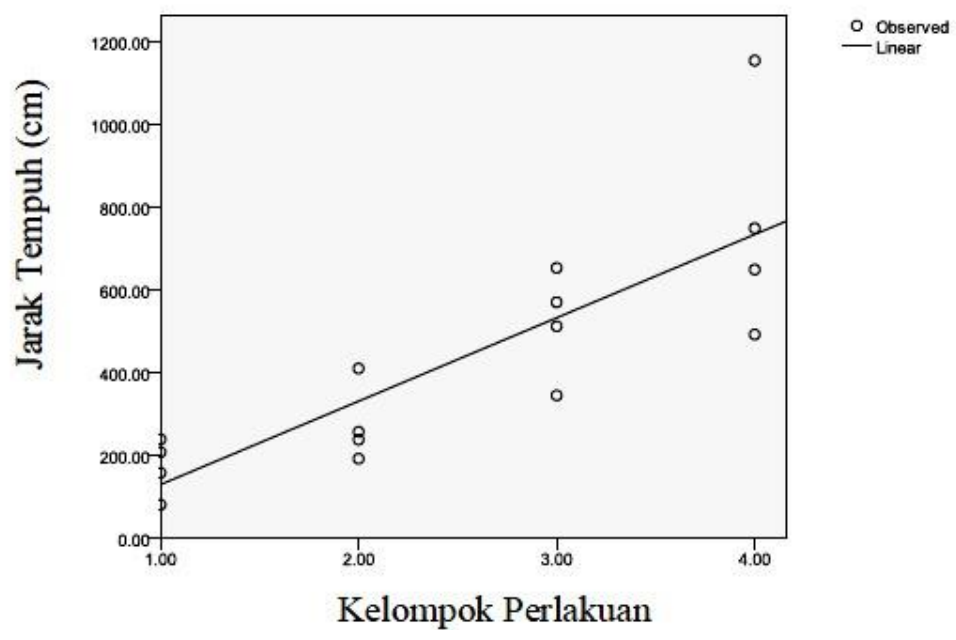

Gambar 2 Sebaran kurva uji regresi antara jumlah pemberian minyak trans dengan DT

RT

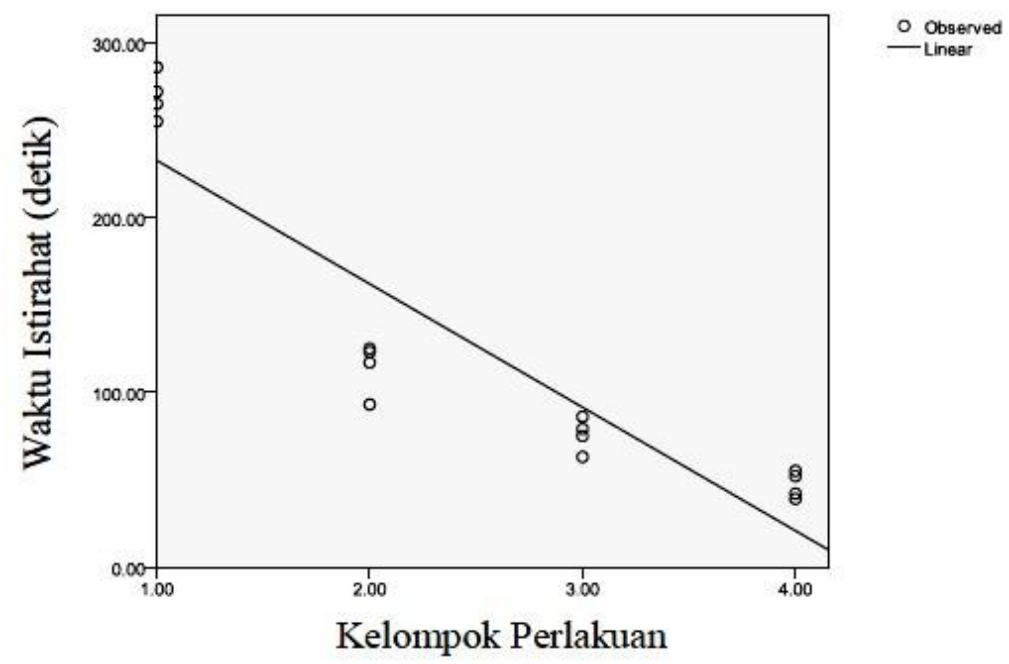

Gambar 3 Sebaran kurva uji regresi antara jumlah pemberian minyak trans dengan RT 
reseptor leptin, sehingga akan makan terus menerus (hiperphagia) walaupun kadar leptin dalam darah sedang tinggi (Guyton dan Hall 2008).

Diet tinggi lemak dapat menyebabkan peningkatan piruvat dehydrogenase kinase (PDK) (Peters et al. 2001). PDK adalah enzim yang berada di dalam otot rangka. Kondisi diet tinggi lemak berkepanjangan menyebabkan peningkatan kadar PDK, sehingga hal ini dapat berakibat meningkatnya aktivitas fisik tikus. Peningkatan aktivitas fisik tikus dengan melakukan perjalanan adalah upaya dalam mencari makan. Hal inilah yang menyebabkan kenaikan DT tikus.

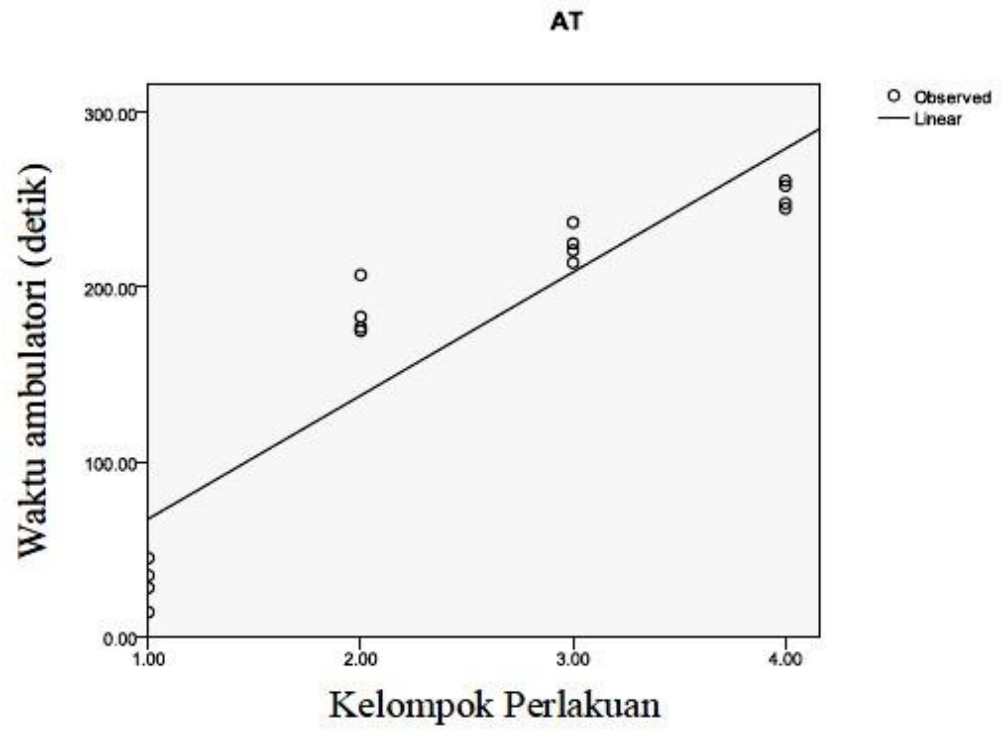

Gambar 4 Sebaran kurva uji regresi antara jumlah pemberian minyak trans dengan AT

\section{Resting time (RT) atau Waktu Istirahat}

Restingtimeadalah waktu yang dibutuhkan untuk tikus beristirahat. Istirahat bagi hewan sangat penting untuk menghemat energi. Hasil pengukuran RT menunjukkan bahwa kelompok perlakuan minyak trans memberikan pengaruh yang nyata terhadap waktu istirahat tikus $(\mathrm{P}<0.05)$.

Hasil pengukuran menunjukkan, adanya penurunan yang nyata pada perlakuan 20\%, 40\% maupun $60 \%$. Hubungan antara konsentrasi minyak trans dengan RT diperoleh dengan melakukan uji regresi. Uji regresi (Gambar 3) memberikan hasil hubungan yang erat antara peningkatan konsumsi minyak trans dengan penurunan RT. Hasil uji regresi menunjukkan persamaan y = $70.625 \mathrm{x}-3.250, \mathrm{r}=0.913$ dan $\mathrm{R} 2=0.834$. Hal ini memberikan arti bahwa pemberian minyak trans mempengaruhi $83.4 \%$ waktu istirahat tikus.

Tikus merupakan hewan pengerat yang hidup secara sosial. Hewan ini hidup secara berkelompok dengan berbagi liang atau sarang. Mereka yang hidup berkelompok saling berinteraksi untuk berbagi area makan (Ebensperger 2001). Di alam liar, wilayah yang dijelajahi tikus adalah 10-8000 m2. Pergerakan tikus yang sedemikian luas dapat berkaitan dengan agresivitas dalam mencari makanan dan minuman, mencari tempat bersarang, kawin ataupun pengenalan lingkungan. Kegiatan ini dilakukan secara alamiah oleh tikus dan diperlukan kemampuan dalam bergerak baik 
lari ataupun berjalan (Jackson 1982).

Menurut Corbett et al. (1986) tikus yang mengalami kenaikan massa adiposa cenderung mengalami penurunan waktu istirahat. Aktivitas tikus yang mengalami diet tinggi minyak trans lebih tinggi dibandingkan dengan tikus kontrol, dalam hal ini tikus selalu merasa lapar sehingga terjadi peningkatan DT, menyebabkan waktu istirahat tikus berkurang. Sementara Milosevi et al. (2005) menjelaskan bahwa tikus dalam keadaan stres akan cenderung banyak melakukan aktivitas. Stres yang dialami tikus salah satunya disebabkan oleh rasa tidak nyaman akibat selalu merasa lapar. Hal ini menyebabkan penurunan waktu istirahat pada tikus.

Ambulatory Time (AT)

Ambulatory Time adalah waktu yang diukur ketika tikus akan memulai suatu gerakan. Gerakan yang dilakukan oleh tikus berupa gerakan stereoptypic seperti grooming, makan, defekasi ataupun urinasi tanpa melakukan perpindahan lokasi. Hasil pengukuran AT memiliki perbedaan yang nyata sehingga dilakukan uji lanjutan dengan uji Duncan dengan selang kepercayaan 95\% $(\alpha=0.05)$. Setelahnya dilakukan uji regresi untuk melihat adanya hubungan penambahan volume minyak trans dengan AT. Hasil pengukuran menunjukkan, adanya peningkatan yang nyata pada perlakuan 20\%, 40\% maupun 60\%. Hasil uji regresi (Gambar 4) menunjukkan hubungan yang erat antara peningkatan konsumsi minyak trans dengan peningkatan AT, dengan persamaan y $=303.250$ $70.625 \mathrm{x}$, nilai $\mathrm{r}=0.913$ dan nilai $\mathrm{R} 2=0.834$. Hal ini menunjukkan bahwa $83.4 \%$ penambahan minyak trans memberikan pengaruh terhadap AT.

Rasa lapar yang ditimbulkan oleh kondisi diet tinggi minyak trans tidak hanya berasal dari hormon leptin saja. Peningkatan massa jaringan adipose mengakibatkan kondisi resistensi insulin (Dewi 2007). Kaitan yang besar antara obesitas dan resistensi insulin mengindikasikan bahwa peningkatan atau penurunan berat badan berkaitan erat dengan sensitivitas insulin (Urukawa 2003). Pada penderita obesitas akan berkembang resistensi terhadap aksi seluler insulin yang ditunjukkan oleh berkurangnya kemampuan insulin untuk menghambat pengeluaran glukosa dari hati serta berkurangnya kemampuan untuk mengambil glukosa dari lemak dan otot (Park et al. 2006). Kondisi ini menyebabkan rendahnya kadar glukosa dalam sel sehingga tikus akan selalu merasa lapar. Hal inilah yang menyebabkan AT meningkat.

\section{SIMPULAN}

Pemberian diet tinggi minyak trans memberikan pengaruh nyata terhadap aktivitas tikus wistar jantan. Perubahan aktivitas yang terjadi yaitu peningkatan jarak tempuh, penurunan waktu istirahat dan peningkatan waktu ambulatori tikus.

\section{DAFTAR PUSTAKA}

Buettner R, Scholmerich J, Bolheimer LC. 2007. High-fat diets: modeling the metabolic disorders of human Obesity in rodents. J Obesity.15: 798-808.

Corbett SW, Stern JS, Keesey RE. 1986. Energy expenditure in rats with dietinducedobesity. Am J Clin Nutr . 44:173-180. 
Dewi M. 2007. Resistensi insulin terkait obesitas: mekanisme endokrin dan intrinsik sel. J of Nutri and Food. 2(2): 49 - 54.

Dhibi M, Brahmi1 F, Mnari A, Houas Z, chargui I, Bchir L, Gazzah N, Alsaif MA and Hammami M. 2011. The intake of high fat diet with different trans fatty acid levels differentially induces oxidative stress and non alcoholic fatty liver disease (NAFLD) in rats. J Metabolism and Nutrition. 8(65): 2-12.

Ebensperger LA. 2001. A review of the evolutionary causes of rodent groupliving.Acta Theriologica. 46(2): 115-144.

Fennema OR. 1996. Food Chemistry, 3rd ed. Marcel Dekker, Inc. New York USA.

Fessenden RJ dan Fessenden JS. 1986. Organic Chemistry Third Edition. University Of Montana. Wadsworth Inc. Massachuset (US).

Friedman JM dan Halaas JL. 1998. Leptin and the regulation of body weight in mammals. Nature Macmillan Publishers Ltd. 395: 764-770.

Guyton AC, Hall JE. 1996. Buku Ajar Fisiologi Kedokteran. Edisi IX. Penerjemah: Setiawan I, Tengadi LMAKA, Santoso A. Jakarta (ID): EGc.

Guyton AC, Hall JE. 2008. Buku Ajar Fisiologi Kedokteran. Edisi XI. Penerjemah: Irawati, Ramadhani D, Indriyani F, Dany F. Jakarta (ID): EGc.

Jackson WB. 1982. Norway rat and allies. In: Wild Mammals of North America (Chapman JA, FeldhamerGA, eds). Baltimore: The Johns Hopkins University Pr.

Ketaren S. 1986. Pengantar Teknologi Minyak dan Lemak Pangan. Jakarta(ID): Penerbit Universitas Indonesia. p.61-143.

Konturek SJ, Konturek JW, Pawlik T, Brzozowki T. 2004. Brain-gut axis and its role in the control of food intake. J Physiol \& Phar. 55:137-154.

Mars M, de Graaf c, de Groot cPGM, van Rossum cTM and Kok FJ. 2006.Fasting leptin and appetite responses induced by a 4-day 65\%-energy-restricted diet. J of Obesity. 30: 122128.

Mattjik AA, Sumertajaya IM. 2006. Perancangan Percobaan dengan Aplikasi SAS dan Minitab.Ed ke-3. Bogor: IPB Pr.

Mercola J. 2010. Scientists Unlock How Trans Fats Harm Your Arteries. Mercola [Internet]. [diunduh 2014 Des 31]. Tersedia pada: http://www.http://articles.mercola.com/sites/ articles/archive/2010/11/16/scientists-unlockhow-trans-fats-harm-your-arteries.aspx.

Millenson JR, Julian CL. 1979. Priciples of Behavioral Analisys. 2nd Ed. The New University of Ultser, Northern Ireland.

Milosevi VS, Trifunovi M, Sekuli B, Sosi B, Filipovi N, Negi N, Nestorovi SM, Manojlovi V, Starcevi c. 2005. chronic Exposure to constant Light Affects Morphology and Secretion of Adrenal Zona Fasciculata Cells in Female Rats. Gen. Physiol. Biophys. 24: 299-309.

Mozaffarian D, Katan MB, Ascherio A, Stampfer MJ, Willet Wc. 2006. Trans fatty Acids and cardiovascular Disease. The N Engl J Med. 354:1601-1613. 
Park J, choe SS, choi AH, Kim KH, Yoon MJ, Suganami T, Ogawa Y, Kim JB. 2006. Increase in glucose-6-phosphate dehydrogenase in adipocytes stimulates oxidative stress and inflammatory signals diabetes. J Diabetes. 55: 2939-2949.

Peters SJ, Robert AH, Pengfei Wu, Pehleman TL, George JF, Heigenhauser LL. 2001. Human skeletal muscle PDH kinase activity and isoform expression during a 3-day high-fat/lowcarbohydrate diet. Am J of Physiology - Endocrinology and Metabolism. 281(6): E1151E1158.

Puspitasari NN. 1996. Buletin Teknik dan Industri Pangan. 7(2): 84-94. [Riskesdas] Riset Kesehatan Dasar. 2010. Laporan Hasil Riset Kesehatan Dasar (Riskesdas) 2010. Kementerian Kesehatan RI, Badan Penelitian Dan Pengembangan Kesehatan(ID).

Schwartz MW. 2001. Brain pathways controlling food intake and body weight. J Exp Biol Med. 226:978-981.

Silver IA, Erecinska M. 1994. Extracellular glucose concentration in mammalian brain: continuous monitoring of changes during increased neuronal activity and upon limitation in oxygen supply in normo-, hypo- and hyperglycemic animals. J Neurosci. 14: 5068-5076.

Tuminah S. 2009. EfekAsam Lemak Jenuh danAsam Lemak Tak Jenuh “Trans” Terhadap Kesehatan. Media Penelitian dan Pengembangan Departemen Kesehatan, Republik Indonesia. Vol XIX, supplemen II. Urakawa H. 2003. Oxidative stress is associated with adiposity and insulin resistance in men. $\mathrm{J}$ of clin endo \& metabolism. 10(88): 4673-4676.

[WHO] World Health Organization. 2003. Diet, Nutrition and the Prevention of chronic Diseases, Report of a Joint. 